\title{
Corrigendum: Carbon Dioxide Emissions along the Lower Amazon River
}

\author{
Henrique O. Sawakuchi ${ }^{1,2 *}$, Vania $\mathrm{Ne}^{3}$, Nicholas D. Ward ${ }^{4,5}$, Maria de Lourdes C. Barros ${ }^{1}$, \\ Aline M. Valerio ${ }^{6}$, William Gagne-Maynard ${ }^{2}$, Alan C. Cunha ${ }^{7}$, Diani F. S. Less ${ }^{7}$, \\ Joel E. M. Diniz ${ }^{7}$, Daimio C. Brito ${ }^{7}$, Alex V. Krusche ${ }^{1}$ and Jeffrey E. Richey ${ }^{2}$ \\ ${ }^{1}$ Centro de Energia Nuclear na Agricultura, Universidade de São Paulo, Piracicaba, Brazil, ${ }^{2}$ School of Oceanography, \\ University of Washington, Seattle, WA, United States, ${ }^{3}$ Instituto Sócio Ambiental e dos Recursos Hídricos, Universidade \\ Federal Rural da Amazônia, Belém, Brazil, " Whitney Laboratory for Marine Bioscience, University of Florida, St. Augustine, \\ FL, United States, ${ }^{5}$ Marine Sciences Laboratory, Pacific Northwest National Laboratory, Sequim, WA, United States, \\ ${ }^{6}$ Departamento de Sensoriamento Remoto, Instituto Nacional de Pesquisas Espaciais, São José dos Campos, Brazil, \\ ${ }^{7}$ Departamento de Meio Ambiente e Desenvolvimento, Universidade Federal do Amapá, Macapá, Brazil
}

Keywords: $\mathrm{GHG}$ emission, $\mathrm{CO}_{2}$ emission, Lower Amazon, $\mathrm{CO}_{2}$ outgassing, river, global $\mathrm{CO}_{2}$ emission

\section{A Corrigendum on}

Carbon Dioxide Emissions along the Lower Amazon River

by Sawakuchi, H. O., Neu, V., Ward, N. D., Barros, M. d. L. C., Valerio, A. M., Gagne-Maynard, W., et al. (2017). Front. Mar. Sci. 4:76. doi: 10.3389/fmars.2017.00076

\section{OPEN ACCESS}

Edited and reviewed by: Marta Álvarez,

Instituto Español de Oceanografía,

Spain

${ }^{*}$ Correspondence:

Henrique O. Sawakuchi,

riqueoliveira@yahoo.com.br

Specialty section:

This article was submitted to

Marine Biogeochemistry,

a section of the journal

Frontiers in Marine Science

Received: 18 July 2020

Accepted: 29 July 2020

Published: 08 September 2020

Citation

Sawakuchi HO, Neu V, Ward ND,

Barros MdLC, Valerio AM,

Gagne-Maynard W, Cunha AC,

Less DFS, Diniz JEM, Brito DC,

Krusche AV and Richey JE (2020)

Corrigendum: Carbon Dioxide Emissions along the Lower Amazon

River. Front. Mar. Sci. 7:688.

doi: 10.3389/fmars.2020.00688
In the original article, there was an error in the upscaling of site-specific flux rates to local emissions for the different areas considered in the paper for the lower Amazon River. Hence, the error propagated throughout our local and global estimates presented in different sections of the paper and Tables 3, 4. Minor mistakes were also in the discharge values for lower and rising sampling season for IDs 5 (South Macapá) and 6 (North Macapá), which are switched in Table $\mathbf{1}$ and the values of Areas 1 and 2 presented in the Methods.

Several corrections have been made to the text of the article and the updated sections are as follows:

Abstract: "We estimate that the lower Amazon River mainstem emits $20 \mathrm{Tg} \mathrm{C}_{\mathrm{C}} \mathrm{ar}^{-1}$ within our study boundaries, or as much as $48 \mathrm{Tg} \mathrm{C}$ year $^{-1}$ if the entire spatial extent to the geographical mouth is considered. Emissions from the Xingu and Tapajós lower tributaries contribute an additional 2.3 $\mathrm{Tg} \mathrm{C}_{\text {year }}{ }^{-1}$. Including these values with updated basin scale estimates and estimates of $\mathrm{CO} 2$ outgassing from small streams we estimate that the Amazon running waters outgasses as much as $0.95 \mathrm{Pg} \mathrm{C}$ year $^{-1}$, increasing the global emissions from inland waters by $15 \%$ for a total of $2.45 \mathrm{Pg} \mathrm{C}$ year $^{-1}$. These results highlight the lower reaches of large rivers as a missing gap in basin-scale and global carbon budgets. In the case of the Amazon River, the previously unstudied tidally-influenced reaches contribute to $5 \%$ of CO 2 emissions from the entire basin."

Methods section, subsection Annual $\mathrm{CO}_{2}$ Emissions from the Lower Amazon River, the first paragraph:

"We divided the main channel into two zones: (Area 1) our study boundaries from Óbidos to Macapá, which has a surface area of $7,118 \mathrm{~km}^{2}$, and (Area 2) the region extending from Macapá to the geographical river mouth, which has an additional surface area of $11,261 \mathrm{~km}^{2}$ (Figure 1)."

Results section, subsection Upscaling $\mathrm{CO}_{2}$ Emissions from the Lower Amazon River:

"The total flux of $\mathrm{CO}_{2}$ from the main channel of the lower Amazon River was calculated for two zones (Figure 1) for each 3-month hydrologic period and annually (Table 3). The most conservative 
TABLE 1 | $\mathrm{CO}_{2}$ fluxes to atmosphere $\left(\mathrm{FCO}_{2}\right)$, partial pressure of $\mathrm{CO}_{2}$ in the water $\left(\mathrm{pCO}_{2}\right)$, gas transfer velocity $\left(k_{600}\right)$ measurements according to site and season (mean $\pm \mathrm{SD}$ ) and measurements of mean depth $(z)$, water velocity $(w)$, discharge $(Q)$ and wind speed $\left(U_{10}\right)$.

\begin{tabular}{|c|c|c|c|c|c|c|c|c|c|}
\hline ID & Site (River) & Sampling season & $\mathrm{FCO}_{2}$ & $\mathrm{pCO}_{2}$ & $k_{600}$ & $z$ & $w$ & $Q$ & $U_{10}$ \\
\hline & & & $\left(\mu \mathrm{mol} \mathrm{m} \mathrm{m}^{-2} \mathrm{~s}^{-1}\right)$ & ( $\mu$ atm) & $\left(\mathrm{cm} \mathrm{h}^{-1}\right)$ & $(m)^{a}$ & $\left(\mathrm{~cm} \mathrm{~s}^{-1}\right)$ & $\left(m^{3} s^{-1}\right)$ & $\left(\mathrm{m} \mathrm{s}^{-1}\right)$ \\
\hline \multirow[t]{4}{*}{1} & Óbidos (Amazon) & Falling & $16.06 \pm 1.68$ & $6148 \pm 326$ & $36.09 \pm 13.78$ & 54.2 & 183 & 257,277 & 6.6 \\
\hline & & High & $9.39 \pm 2.04$ & $6106 \pm 441$ & $17.74 \pm 3.16$ & 51.5 & 192 & 253,959 & - \\
\hline & & Low & $11.79 \pm 4.04$ & $2458 \pm 6$ & $54.32 \pm 1.79$ & 49.4 & 106 & 122,274 & - \\
\hline & & Rising & $5.89 \pm 3.45$ & $2572 \pm 57$ & $27.62 \pm 16.59$ & 32.8 & 106 & 122,172 & 4.5 \\
\hline \multirow[t]{4}{*}{2} & Alter do Chão (Tapajós) & Falling & 1.07 & 450 & - & 23.5 & 20 & 10,018 & 1.5 \\
\hline & & High & 1.75 & 1650 & 16.03 & & & 24,428 & - \\
\hline & & Low & 0.76 & 449 & - & 24 & 9 & 3,658 & - \\
\hline & & Rising & 2.4 & 896 & - & 10.7 & 27 & 10,480 & 5.4 \\
\hline \multirow[t]{4}{*}{3} & Almeirim (Amazon) & Falling & $13.59 \pm 4.25$ & $3857 \pm 583$ & $40.69 \pm 14.71$ & 28.1 & 182 & 282,688 & 3.5 \\
\hline & & High & 15.09 & $5406 \pm 24$ & 30.97 & 29.1 & 187 & 298,913 & - \\
\hline & & Low & $5.84 \pm 1.97$ & $1657 \pm 168$ & $52.11 \pm 20.15$ & 26.2 & 87 & 124,831 & - \\
\hline & & Rising & $2.49 \pm 1.1$ & $1714 \pm 165$ & $30.38 \pm 15.5$ & 16.8 & 102 & 137,117 & 3.2 \\
\hline \multirow[t]{4}{*}{4} & Porto de Moz (Xingu) & Falling & 2.39 & 508 & $174.22^{*}$ & & & 3,093 & 7.5 \\
\hline & & High & $7.85^{\star}$ & $5001^{*}$ & 17.06 & & & 16,804 & - \\
\hline & & Low & 0.87 & 506 & $133.66^{\star}$ & & & 1,674 & - \\
\hline & & Rising & 2.07 & 1117 & 42.92 & & & 14,288 & 4.1 \\
\hline \multirow[t]{4}{*}{5} & Macapá South (Amazon) & Falling & $3.9 \pm 1.39$ & $2471 \pm 275$ & $18.97 \pm 7.1$ & 24.6 & 50 & 146,473 & 4.8 \\
\hline & & High & $17.27 \pm 0.26$ & $4761 \pm 3$ & $42.27 \pm 0.38$ & 24 & 72 & 204,056 & - \\
\hline & & Low & 1.74 & 1490 & 16.03 & 17.5 & 31 & 132,998 & - \\
\hline & & Rising & $2.45 \pm 0.99$ & $1645 \pm 197$ & $28.65 \pm 5.67$ & 10.6 & 28 & 103,593 & 3.7 \\
\hline \multirow[t]{4}{*}{6} & Macapá North (Amazon) & Falling & $5.47 \pm 3.05$ & $3400 \pm 565$ & $20.51 \pm 15.36$ & 19.4 & 55 & 113,371 & 3.4 \\
\hline & & High & $16.79 \pm 1.99$ & $4489 \pm 618$ & $45.47 \pm 13.08$ & 18.5 & 64 & 140,692 & - \\
\hline & & Low & $3.71 \pm 0.62$ & $1272 \pm 158$ & $46.98 \pm 0.04$ & 22.7 & 48 & 61,539 & - \\
\hline & & Rising & $2.19 \pm 0.87$ & $1281 \pm 22$ & $15.8 \pm 0.66$ & 9.4 & 37 & 53,265 & 3.4 \\
\hline
\end{tabular}

*Outliers removed for statistical analysis.

estimates (Area 1) only included the boundaries of this study, from Óbidos to Macapá, which had an average wetted surface area of $7,118 \mathrm{~km}^{2}$. The flux of $\mathrm{CO}_{2}$ from Area 1 was $20 \mathrm{Tg} \mathrm{C}$ year $^{-1}$. Area 2 extends from Macapá to the region of the mouth where the connection to land terminates, which had an additional surface area of $11,261 \mathrm{~km}^{2}$. Area $2 \mathrm{had}$ a total $\mathrm{CO}_{2}$ flux of $28 \mathrm{Tg}$ $\mathrm{C}$ year ${ }^{-1}$, based on an extrapolation of average values measured across the north and south Macapá channels (Table 3). The sum of fluxes for these two zones, or the total emissions from Óbidos to the actual river mouth was $48 \mathrm{Tg} \mathrm{C}$ year $^{-1}$. The emissions from the lower Tapajós and Xingu rivers were 1.40 and $0.86 \mathrm{Tg} \mathrm{C}$ year $^{-1}$, respectively. Including these two tributaries to the budget would add more $2.26 \mathrm{Tg} \mathrm{C}_{\mathrm{Cear}}{ }^{-1}$."

Discussion section, the eighth paragraph:

"Here we considered two different areas for upscaling annual $\mathrm{CO}_{2}$ emissions from the lower Amazon River. Our most conservative estimate, including the area from Óbidos to Macapá (Area 1), was $20 \mathrm{Tg} \mathrm{C}$ year $^{-1}$. Area 2, which extends to the geographic terminus of the river, is a relatively short distance compared to Area 1, but covers $58 \%$ more surface area than the Óbidos to Macapá reach (Table 3). Applying the average $\mathrm{FCO}_{2}$ observed near Macapá, we estimate Area 2 to emit $28 \mathrm{Tg} \mathrm{C}$ year $^{-1}$, which combined with the upstream section totalize $48 \mathrm{Tg} C$ year $^{-1}$. Emissions from the Xingu and Tapajós tributaries contribute an additional $2.3 \mathrm{Tg} \mathrm{C}_{\mathrm{Cear}}{ }^{-1}$, resulting in a total flux of $51 \mathrm{Tg} \mathrm{C}$ year $^{-1}$ from the lower Amazon River basin. This estimate for the lower Amazon River, alone, is roughly $53 \%$ in magnitude compared to $\mathrm{CO}_{2}$ emissions from all rivers in the conterminous United States (97 $\mathrm{Tg} \mathrm{C}_{\text {year }}{ }^{-1}$; Butman and Raymond, 2011) and $\sim 12 \%$ of past estimates of basin-scale emissions from the Amazon (0.47 Pg C year ${ }^{-1}$; Richey et al., 2002).”

Discussion section, the ninth paragraph:

"Adding our estimations of the fluxes estimated for Area 1 and the sum of Area 1 and 2 to estimations by Richey et al. (2002) increases basin-scale $\mathrm{CO}_{2}$ outgassing to 0.49 and 0.52 Pg C year ${ }^{-1}$, respectively. A recent re-evaluation of basin-wide outgassing estimates upstream of Óbidos was done using a combination of direct flux measurements and more detailed $\mathrm{k}$ values calculations along with observations by Alin et al. (2011) for tributaries and streams. It was estimated that basin scale $\mathrm{CO}_{2}$ outgassing upstream from Óbidos was roughly $0.8 \mathrm{Pg} \mathrm{C}$ year $^{-1}$ (Rasera et al., 2013). First order streams add an additional $0.1 \mathrm{Pg}$ $\mathrm{C}$ year ${ }^{-1}$ to basin scale $\mathrm{CO}_{2}$ fluxes in the Amazon basin (Johnson et al., 2008). Adding our estimates for the lower river to these values results in basin-wide budgets of $0.92 \mathrm{Pg} \mathrm{C}_{\text {year }}{ }^{-1}$ and 0.95 $\mathrm{Pg} \mathrm{C}$ year $^{-1}$ for Area 1 and the sum of Area 1 and 2, respectively (Table 4). Replacing these new estimates for the Amazon in the 
TABLE 3 | Seasonal $\mathrm{CO}_{2}$ emissions in the Amazon River channel considering different areas.

\begin{tabular}{lcccc}
\hline Season & \multicolumn{4}{c}{$\mathbf{C O}_{\mathbf{2}}$ emission $\left(\mathbf{T g ~} \mathbf{~}\right.$ year $\left.{ }^{-\mathbf{1}}\right)$} \\
\cline { 2 - 5 } & Area 1 & Area 2 & Tributaries & Total \\
\hline Area $\left(\mathrm{km}^{2}\right)$ & 7,118 & 11,261 & 3,769 & 22,149 \\
Falling & 5.4 & 5.0 & 0.5 & 10.9 \\
High & 8.9 & 18.1 & 0.6 & 27.6 \\
Low & 3.9 & 2.9 & 0.3 & 7.1 \\
Rising & 1.9 & 2.5 & 0.8 & 5.1 \\
Total & 20.0 & 28.5 & 2.3 & 50.8 \\
\hline
\end{tabular}

Estimates for tributaries only include the lower reaches measured in this study.

TABLE 4 | $\mathrm{CO}_{2}$ emission estimates for rivers and streams in the Amazon.

\begin{tabular}{|c|c|c|}
\hline & $\begin{array}{l}\mathrm{CO}_{2} \text { emission } \\
\left(\mathrm{Pg} \mathrm{C}_{\text {year }}^{-1}\right)\end{array}$ & References \\
\hline Lower Amazon Area 1 & 0.020 & This study \\
\hline $\begin{array}{l}\text { Lower Amazon Area } 1 \\
+ \text { Area } 2+\text { tributaries }\end{array}$ & 0.051 & This study \\
\hline $\begin{array}{l}\text { Large rivers in Amazon } \\
\text { upstream Óbidos }\end{array}$ & 0.47 & Richey et al., 2002 \\
\hline $\begin{array}{l}\text { Large rivers in Amazon } \\
\text { upstream Óbidos }\end{array}$ & 0.80 & Rasera et al., 2013 \\
\hline Amazon streams & 0.10 & Johnson et al., 2008 \\
\hline
\end{tabular}

global $\mathrm{CO}_{2}$ budget by Raymond et al. (2013) increases the global budget by as much as $18 \%$ for a total of $2.48 \mathrm{Pg} \mathrm{C}_{\text {year }}{ }^{-1}$."

Discussion section, the tenth paragraph:

"In the case of this updated global budget, the Amazon River represents $38 \%$ of global $\mathrm{CO}_{2}$ emissions. However, the contribution of other tropical rivers to the global budget are likely also underestimated considering that most tropical rivers are even less well-characterized than the Amazon, particularly in the lower reaches, where we've demonstrated that emissions can be high relative to the rest of the basin. Furthermore, we have not included the entirety of the Amazon in our newest budgets. For example, the Tapajós and Xingu rivers were not included due to their large spatial expanse and minimal data coverage. The lower portion of these tributaries, alone (Figure 1), emit roughly $2.3 \mathrm{Tg} \mathrm{C}$ year $^{-1}$, and these estimates do not encompass their entire surface area nor potentially elevated $\mathrm{CO}_{2}$ concentrations closer to their headwaters."

\section{REFERENCES}

Abril, G., Martinez, J. M., Artigas, L. F., Moreira-Turcq, P., Benedetti, M. F., Vidal, L., et al. (2014). Amazon River carbon dioxide outgassing fuelled by wetlands. Nature 505, 395-398. doi: 10.1038/nature12797

Alin, S. R., Rasera, M. F. F. L., Salimon, C. I., Richey, J. E., Holtgrieve, G. W., Krusche, A. V., et al. (2011). Physical controls on carbon dioxide transfer velocity and flux in low-gradient river systems and implications for regional carbon budgets. J. Geophys. Res. Biogeosci. 116:G01009. doi: 10.1029/2010jg001398
Discussion section, the eleventh paragraph:

"Another factor that can lead to an underestimation of basinwide budgets is not including Amazon River water that travels further offshore from Area 2 and along the coastline. For example, the Amazon River can remain unmixed with the ocean as far as $60 \mathrm{~km}$ offshore from Area 2 (Molinas et al., 2014). Abril et al. (2014) estimated that only $18 \%$ of the $\mathrm{CO}_{2}$ from a point source would be degassed in a stretch of approximately $150 \mathrm{~km}$ downstream in the Amazon River taking into account a $\mathrm{k}$-value of $15 \mathrm{~cm} \mathrm{~h}^{-1}$ and water current of $150 \mathrm{~cm} \mathrm{~s}^{-1}$. Thus, it is reasonable to assume that the mouth of the Amazon is the last point source of $\mathrm{CO}_{2}$ to the Amazon plume, sustaining significant emissions for a significant distance offshore. This region, along with near-shore coastal waters, is not included in any studies of $\mathrm{CO}_{2}$ cycling in the Amazon River plume in the Atlantic Ocean due to a lack of sampling and terrestrial contamination of remote sensing products by adjacency effect near-shore (Cooley et al., 2007; Subramaniam et al., 2008). We estimate that Area 3 may emit up to an additional $31 \mathrm{Tg} \mathrm{C}$ year ${ }^{-1}$, but note that this is a simple calculation based on measurements at Macapá. Further exploration of this offshore area is essential for constraining the total basin-wide $\mathrm{CO}_{2}$ flux. Although it is too early to confidently incorporate this offshore freshwater region (Area 3) into basinwide budgets, this rough estimation highlights that expansive regions of offshore freshwater plumes may be an important missing gap in aquatic carbon budgets."

Concluding Remarks section, the first paragraph, the third sentence:

"Here we show that the lower reaches of the Amazon River are an active area in terms of freshwater $\mathrm{CO}_{2}$ emissions from the Amazon, and perhaps the world, although, lower river reaches have yet to be adequately studied in other comparable tropical systems."

Concluding Remarks section, the second paragraph, the first and second sentences:

"The enormous surface area of the lower Amazon River $\left(18,379 \mathrm{~km}^{2}\right)$ is slightly less than half of the area of rivers and stream in the conterminous United States (Butman and Raymond, 2011), and similarly emits roughly half as much $\mathrm{CO}_{2}$ to the atmosphere. This area alone releases an amount of $\mathrm{CO}_{2}$ in the same order of magnitude than the uptake by the Amazon River plume in the Atlantic Ocean (Kortzinger, 2003; Cooley et al., 2007; Subramaniam et al., 2008)."

The authors apologize for these errors and state that they do not change the scientific conclusions of the article in any way. The original article has been updated.

Butman, D., and Raymond, P. A. (2011). Significant efflux of carbon dioxide from streams and rivers in the United States. Nat. Geosci. 4, 839-842. doi: 10.1038/ngeo1294

Cooley, S. R., Coles, V. J., Subramaniam, A., and Yager, P. L. (2007). Seasonal variations in the Amazon plume-related atmospheric carbon sink. Glob. Biogeochem. Cycles 21:GB3014. doi: 10.1029/2006gb002831

Johnson, M. S., Lehmann, J., Riha, S. J., Krusche, A. V., Richey, J. E., Ometto, J., et al. (2008). $\mathrm{CO}_{2}$ efflux from Amazonian headwater streams represents a significant fate for deep soil respiration. Geophys. Res. Lett. 35:L17401. doi: $10.1029 / 2008$ gl034619 
Kortzinger, A. (2003). A significant $\mathrm{CO}_{2}$ sink in the tropical Atlantic Ocean associated with the Amazon River plume. Geophys. Res. Lett. 30:2287. doi: $10.1029 / 2003 \mathrm{gl} 018841$

Molinas, E., Vinzon, S. B., Vilela, C. D. X., and Gallo, M. N. (2014). Structure and position of the bottom salinity front in the Amazon Estuary. Ocean Dynamics 64, 1583-1599. doi: 10.1007/s10236-014-0763-0

Rasera, M. F. F. L., Krusche, A. V., Richey, J. E., Ballester, M. V. R., and Victória, R. L. (2013). Spatial and temporal variability of $\mathrm{pCO}_{2}$ and $\mathrm{CO}_{2}$ efflux in seven Amazonian Rivers. Biogeochemistry 116, 241-259. doi: 10.1007/s10533-013-9854-0

Raymond, P. A., Hartmann, J., Lauerwald, R., Sobek, S., McDonald, C., Hoover, M., et al. (2013). Global carbon dioxide emissions from inland waters. Nature 503, 355-359. doi: 10.1038/nature 12760

Richey, J. E., Melack, J. M., Aufdenkampe, A. K., Ballester, V. M., and Hess, L. L. (2002). Outgassing from Amazonian rivers and wetlands as a large tropical source of atmospheric $\mathrm{CO}_{2}$. Nature 416, 617-620. doi: 10.1038/ $416617 \mathrm{a}$

Subramaniam, A., Yager, P. L., Carpenter, E. J., Mahaffey, C., Bjorkman, K., Cooley, S., et al. (2008). Amazon River enhances diazotrophy and carbon sequestration in the tropical North Atlantic Ocean. Proc. Natl. Acad. Sci. U.S.A. 105, 10460-10465. doi: 10.1073/pnas.07102 79105

Copyright (C) 2020 Sawakuchi, Neu, Ward, Barros, Valerio, Gagne-Maynard, Cunha, Less, Diniz, Brito, Krusche and Richey. This is an open-access article distributed under the terms of the Creative Commons Attribution License (CC BY). The use, distribution or reproduction in other forums is permitted, provided the original author(s) and the copyright owner(s) are credited and that the original publication in this journal is cited, in accordance with accepted academic practice. No use, distribution or reproduction is permitted which does not comply with these terms. 